\title{
Gambaran histologik hati pada kelinci yang diinduksi lemak dengan pemberian ekstrak beras hitam
}

\author{
${ }^{1}$ Yosua R. Somba \\ ${ }^{2}$ Djon Wongkar \\ ${ }^{2}$ Shane H. R. Ticoalu \\ ${ }^{3}$ Alexander S. L. Bolang
}

\author{
${ }^{1}$ Kandidat Skripsi Fakultas Kedokteran Universitas Sam Ratulangi Manado \\ ${ }^{2}$ Bagian Anatomi Histologi Fakultas Kedokteran Universitas Sam Ratulangi Manado \\ ${ }^{3}$ Bagian Ilmu Gizi Fakultas Kedokteran Universitas Sam Ratulangi Manado \\ Email: yosuarichard_somba@yahoo.com
}

\begin{abstract}
Dyslipidemia is a disorder of fat metabolism which is marked by increase of one or more fractions of fat in the blood. Due to the high rate of dyslipidemia cases, people begin to improve their lifestyle, such as consuming black rice. Black rice (Oryza sativa L.) is a local variety of rice that contains pigments which are different from other types of rice. Black rice extract is beneficial for lowering LDL cholesterol level and significantly increasing HDL cholesterol level besides its antioxidant effect against reactive oxygen species. This was an experimental posttestonly control group design. Subjects were three New Zealand White rabbits, divided into three groups. Group A was fed with standard food for rabbit; group B was fed with standard food for rabbit and fat; group $\mathrm{C}$ was fed with standard foot for rabbit, fat, and black rice extract for 28 days. Blood total and LDL cholesterol were examined on the first day and after 28 days of treatment. The three groups were terminated and their liver tissues were processed for histological examination. The histological results were as follows: Group one showed small fat vacuoles around the hepatocyte nuclei; group two showed large fat vacuoles around the hepatocyte nuclei, signet rings, and coalescence of fat vacuoles; group three showed fat vacuoles around the hepatocyte nuclei, a few signet rings without coalescence of fat vacuoles. Conclusion: Black rice extract could reduce fat vacuoles in liver tissue.
\end{abstract}

Keywords: fat, black rice extract, dyslipidemia, fatty liver

\begin{abstract}
Abstrak: Dislipidemia adalah kelainan metabolisme lemak yang ditandai peningkatan salah satu atau lebih dari fraksi lemak di dalam darah. Meningkatnya kasus dislipidemia menyebabkan banyak orang beralih ke gaya hidup sehat, antara lain mengonsumsi beras hitam. Beras hitam (Oryza sativa L.) merupakan beras varietas lokal dengan pigmen yang berbeda dari beras lain oleh karena kandungan antosianin. Ekstrak beras hitam bermanfaat untuk menurunkan kadar kolesterol total dan LDL secara bermakna, meningkatkan kadar kolesterol HDL, serta memiliki efek antioksidan terhadap reactive oxygen species. Jenis penelitian ini ialah experimental posttest-only control group design. Sampel penelitian ini ialah kelinci New Zealand White sebanyak 3 ekor yang dibagi menjadi 3 kelompok. Kelompok A diberi pakan standar; kelompok B diberi pakan standar dan lemak; dan kelompok C diberi pakan standar dengan lemak dan ekstrak beras hitam selama 28 hari. Pemeriksaan kkolesterol total dan LDL dilakukan pada awal penelitian dan 28 hari setelah perlakuan 28 hari. Kelinci diterminasi untuk pengambilan jaringan hati yang kemudian dibuat sediaan histologik. Hasil pemeriksaan histologik ialah sebagai berikut: Kelompok 1 menunjukkan adanya vakuola lemak kecil-kecil disekitar nukleus; kelompok 2 menunjukkan adanya vakuola lemak yang luas di sekitar nukleus, gambaran signet ring, dan penggabungan vakuola lemak; kelompok 3 menunjukkan adanya vakuola lemak disekitar nukleus dengan beberapa gambaran signet ring tanpa penggabungan vakuola lemak. Simpulan: Ekstrak beras hitam dapat mengurangi vakuola lemak pada jaringan hati
\end{abstract}

Kata kunci: lemak, ekstrak beras hitam, dislipidemia, perlemakan hati 
Beras merupakan makanan yang penting bagi masyarakat negara Asia. Terdapat beberapa jenis beras yang memiliki pigmen warna misalnya beras merah dan hitam. ${ }^{1} \mathrm{Di}$ Indonesia beras menyumbang energi, protein, dan zat besi masing-masing sebesar $63,1 \%$, 37,7\% dan 25-30\% dari total kebutuhan tubuh. ${ }^{2}$

Beras hitam (Oryza sativa L) merupakan beras varietas lokal berpigmen, yang berbeda dengan beras putih atau beras warna lain. Beras hitam memiliki perikarp, aleuron, dan endosperm yang berwarna merah-biru-ungu pekat. Warna tersebut menunjukkan adanya kandungan antosianin yaitu sianidin-3-glukosida dan peonidin-3glukosida. Beras hitam memiliki beberapa keunggulan yaitu nasinya lunak dan wangi, serta pulen; hal ini dikarenakan beras hitam memiliki kandungan amilosa sebesar $22,97 \%$. Selain memiliki sifat yang pulen beras hitam memiliki kandungan beta karoten dan antosianin sebesar 804,16 $\mathrm{mg} / 100 \mathrm{~g}$. Beras hitam juga mengandung protein tinggi, vitamin, dan mineral seperti besi, seng, dan fosfor dibandingkan beras putih, yang tergantung pada varietas dan tipe tanah habitatnya. Selain itu, beras hitam mempunyai kandungan serat pangan (dietary fiber) dan hemiselulosa masingmasing sebesar 7,5\% dan 5,8\%, sedangkan beras putih hanya sebesar $5,4 \%$ dan $2,2 \%$. $^{1,3}$

Ekstrak beras hitam (EBH) memiliki khasiat untuk kesehatan yaitu memiliki efek anti oksidan, anti inflamasi, dan juga sebagai agen kemopreventif. Penelitian lanjut saat ini membuktikan bahwa $\mathrm{EBH}$ bermanfaat untuk menurunkan kadar kolesterol total dan low density lipoprotein cholesterol (LDL-C) secara bermakna, peningkatan kadar high density lipoprotein cholesterol (HDL-C), serta memiliki efek antioksidan terhadap reactive oxygen species (ROS). ${ }^{1}$

Dislipidemia adalah kelainan metabolisme lemak yang ditandai peningkatan salah satu atau lebih dari fraksi lemak di dalam darah, seperti kolesterol, kolesterol ester, fosfolipid, dan trigliserida. Kelainan komponen lemak yang utama meliputi peningkatan kadar kolesterol total dan kolesterol LDL (LDL-C) (hiperkolesterolemia), peningkatan kadar trigliserida (hipertrigliseridemia), serta penurunan kadar kolesterol HDL (HDL-C). Hasil penelitian melaporkan bahwa kasus dislipidemia berat di Indonesia dengan kadar kolesterol total $\geq 240 \mathrm{mg} / \mathrm{dl}$ paling banyak ditemukan di Jakarta dan Padang (>56\%) sedangkan di kota besar lainnya seperti Bandung dan Yogyakarta mencapai $52,2 \%$ dan $27,7 \%{ }^{4}$

Dislipidemia dapat mengakibatkan perlemakan hepar (fatty-liver), sehingga hepatosit mengalami kerusakan dan peningkatan aktivitas enzim-enzim transaminase yang merupakan penanda gangguan fungsi hepar. Dislipidemia sendiri merupakan faktor risiko untuk terjadinya steatosis hati yang bila tidak ditangani dapat berkembang menjadi sirosis hati.

Steatosis hati termasuk dalam kelompok non-alcoholic fatty liver disease (NAFLD). Selain itu, risiko penyakit kardiovaskular di antara subyek dengan NAFLD juga meningkat. Prevalensi NAFLD di antara orang dewasa Amerika Serikat dan negara Barat lainnya diperkirakan sekitar 30\%. Prevalensi NAFLD lebih tinggi pada subyek obes dan penyandang diabetes melitus tipe 2 (DMT2) yaitu 57\% pada subyek obes, 70\% pada subyek dengan DMT2, dan 90\% pada subyek yang obes berat. ${ }^{4,5}$

Manfaat ekstrak beras hitam sudah mulai menarik perhatian peneliti-peneliti yang membahas peran ekstrak beras hitam dalam menurunkan kadar kolesterol total dan LDL, serta sebagai antioksidan. Penelitian ini bertujuan untuk mengamati perubahan yang terjadi pada hati yang mengalami dislipidemia yang diberikan ekstrak beras hitam terhadap hewan coba kelinci

\section{METODE PENELITIAN}

Jenis penelitian yaitu experimental posttest-only control group design. Subjek perlakuan pada penelitian ini ialah tiga hewan coba kelinci New Zealand White, 
dengan kriteria inklusi yaitu: Hewan sehat dan usia hewan homogen (3 bulan). Sebelum penelitian, terlebih dahulu dilakukan adaptasi hewan coba di dalam kandang kelinci selama 2 minggu dengan suhu ruangan $24^{0} \mathrm{C}$, kemudian dilakukan pengambilan darah awal untuk pemeriksaan kolesterol total dan LDL. Perlakuan terhadap 3 kelompok kelinci yaitu: pemberian pakan standar pada kelompok kontrol negatif; diet tinggi lemak pada kelompok kontrol positif; dan diet tinggi lemak dengan ekstrak beras hitam pada kelompok perlakuan. Perlakuan diberikan selama 28 hari. Setelah 28 hari dilakukan pengambilan darah untuk pemeriksaan kolesterol lalu kelinci diterminasi untuk pengambilan organ hati lalu dibuat sediaan yang kemudian dianalisis.

\section{HASIL PENELITIAN}

Tabel 1 dan 2 memperlihatkan hasil pemeriksaan kadar kolesterol total dan LDL

Tabel 1. Hasil Pemeriksaan kolesterol LDL

\begin{tabular}{ccccc}
\hline $\begin{array}{c}\text { Kelompok } \\
\text { kelinci }\end{array}$ & $\begin{array}{c}\text { Berat } \\
\text { awal } \\
(\mathrm{kg})\end{array}$ & $\begin{array}{c}\text { Berat } \\
\text { akhir } \\
(\mathrm{kg})\end{array}$ & $\begin{array}{c}\text { LDL } \\
\text { awal } \\
(\mathrm{mg} / \mathrm{dL})\end{array}$ & $\begin{array}{c}\text { LDL } \\
\text { akhir } \\
(\mathrm{mg} / \mathrm{dL})\end{array}$ \\
\hline $\mathrm{A}$ & 1,8 & 2,5 & 13 & 13 \\
$\mathrm{~B}$ & 2,2 & 3 & 4 & 118 \\
$\mathrm{C}$ & 2,3 & 2,9 & 11 & 9 \\
\hline
\end{tabular}

Tabel 2. Hasil Pemeriksaan kolesterol total (KT)

\begin{tabular}{c|c|c|c|c}
\hline $\begin{array}{c}\text { Kelompok } \\
\text { kelinci }\end{array}$ & $\begin{array}{c}\text { Berat } \\
\text { awal }\end{array}$ & $\begin{array}{c}\text { Berat } \\
\text { akhir }\end{array}$ & $\begin{array}{c}\text { KT } \\
\text { awal }\end{array}$ & $\begin{array}{c}\text { KT } \\
\text { akhir }\end{array}$ \\
\hline A & 1.8 & 2.5 & 58 & 49 \\
B & 2.2 & 3 & 49 & 199 \\
C & 2.3 & 2.9 & 60 & 50 \\
\hline
\end{tabular}

*ket : A : Kontrol negatif

B : Kontrol positif

C : Perlakuan

Pada kelompok kontrol negatif (Gambar 1) ditemukan vakuola lemak dalam hepatosit. Pada kelompok kontrol positif (Gambar 2) ditemukan vakuola lemak yang luas di dalam hepatosit, gambaran signet ring, serta pengabungan vakuola lemak. Pada kelompok perlakuan (Gambar 3) ditemukan vakuola lemak di dalam hepatosit serta beberapa gambaran signet ring.

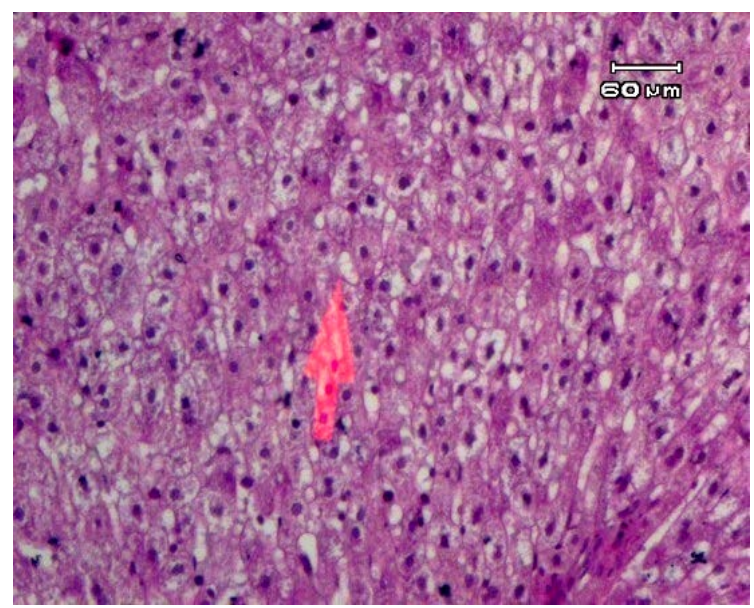

Gambar 1. Kelompok kontrol negatif

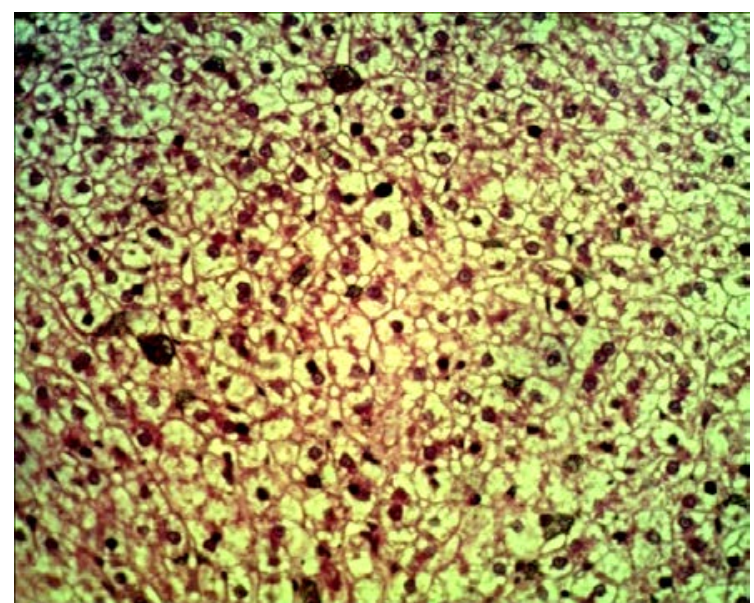

Gambar 2. Kelompok kontrol positif

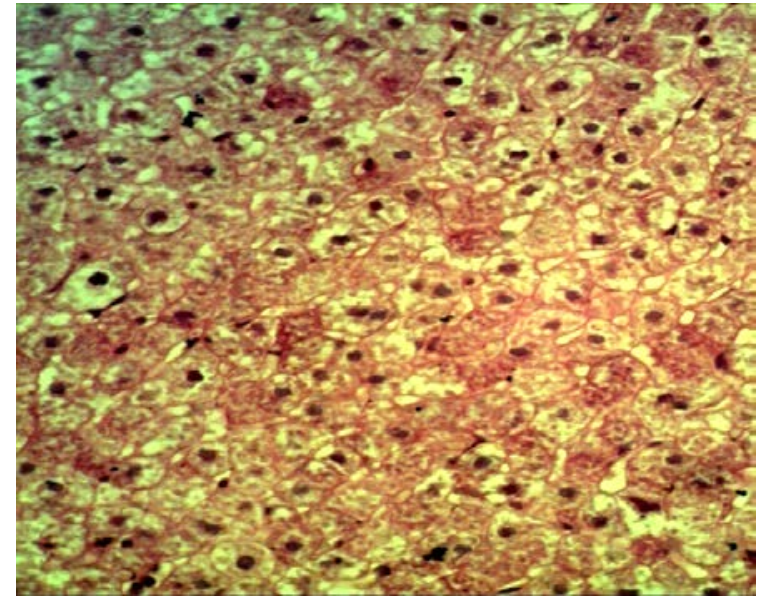

Gambar 3. Kelompok perlakuan 


\section{BAHASAN}

Sesuai hasil pengamatan mikroskopik hati pada ketiga kelompok kelinci, untuk kelompok kontrol negatif ditemukan vakuola lemak disekitar nukleus hepatosit. Hal ini dapat disebabkan oleh pemberian pakan yang mengandung lemak pada waktu adaptasi dan perlakuan. Selain itu, penambahan usia kelinci dan kadar stres akibat tetap didalam kandang dapat meningkatkan profil kadar lemak kelinci. ${ }^{6}$ Adanya vakuola lemak menunjukkan bahwa hati sudah mengalami perlemakan hati mikrovesikuler. ${ }^{7-10}$

Pada kelompok kontrol positif ditemukan vakuola lemak yang luas disekitar nukleus, gambaran signet ring, dan penggabungan vakuola lemak yang dapat menyebabkan fatty cyst. $^{7-9}$ Hal ini diakibatkan oleh lemak babi yang mengandung asam lemak jenuh yang tinggi. Walaupun asam lemak jenuh babi (21\%) tidak sebesar asam jenuh lemak sapi (68\%), namun lemak babi memiliki kandungan asam lemak jenuh ganda yang jauh lebih besar (25\%) daripada lemak sapi $(1,2 \%) .{ }^{11}$ Asam lemak jenuh meningkatkan kadar kolesterol total, trigliserida dan kolesterol LDL, dan konsumsi yang berlebihan dapat menyebabkan dislipidemia oleh karena peningkatan kadar kolesterol. ${ }^{12}$ Akumulasi asam lemak jenuh dan trigliserida dalam hepatosit yang berlebihan dapat menyebabkan steatosis hati. Berdasarkan gambaran histologik hati kelinci kelompok kontrol positif, diduga hati sudah mengalami perlemakan hati makrovesikuler. ${ }^{13}$

Pada kelompok perlakuan ditemukan vakuola lemak disekitar nukleus, dengan gambaran signet ring tanpa penggabungan vakuola lemak. Berdasarkan hasil gambaran mikroskopik, diketahui bahwa kelinci kelompok perlakuan mengalami perlemakan hati mikrovesikuler. ${ }^{7-10}$ Pemberian ekstrak beras hitam diharapkan dapat menurunkan perlemakan hati, tetapi pada penelitian ini penurunan perlemakan hati tidak terjadi secara maksimal. Hal ini mungkin diakibatkan oleh beberapa hal, yaitu: pemberian pakan yang mengandung lemak pada saat adaptasi dan perlakuan; tidak terserapnya ekstrak beras hitam secara maksimal oleh karena pemberian ekstrak dicampurkan dengan air mineral; dan kadar stres tinggi pada kelinci yang menyebabkan peningkatan profil lipid kelinci. $^{6}$

\section{SIMPULAN}

Berdasarkan hasil penelitian dapat disimpulkan bahwa kelinci yang diberikan diet tinggi lemak menunjukkan adanya kerusakan hati berupa vakuola lemak yang luas disekitar nukleus, gambaran signet ring, dan penggabungan antara vakuola lemak yang dapat menyebabkan fatty cyst dan kelinci yang diberikan diet tinggi lemak dengan ekstrak beras hitam menunjukkan adanya kerusakan berupa vakuola lemak di sekitar nukleus dengan beberapa gambaran signet ring tanpa penggabungan antara vakuola lemak. Hal ini menunjukan bahwa pemberian ekstrak beras hitam dapat mengurangi kerusakan hati dengan menurunkan kadar lemak.

\section{DAFTAR PUSTAKA}

1. Pratiwi A. Analisis antosianin dan kandungan nutrien pada bekatul beras hitam (Oryza Sativa L. CV Cempo Ireng Sayegan Yogyakarta) [Tesis]. Yogyakarta: Universitas Gadjah Mada; 2014.

2. Indrasari SD. Kandungan besi varietas padi. Warta Penelitian dan Pengembangan Pertanian. 2006;28(6):13-4.

3. Sa'adah IR, Subejo, Supriyanta. Keragaman warna gabah dan warna beras varietas lokal padi beras hitam (Oryza Sativa L.) yang dibudidayakan oleh petani Kabupaten Sleman, Bantul, dan Magelang. Vegetalika. 2013;2(3):13-5.

4. Hariyanto VA. Efek samping jus buah belimbing wuluh (Averrhoa bilimbi L.) terhadap kadar GGT (gamma glutamyl transferase) tikus jantan galur Wistar [Tesis]. Bandung: Universitas Kristen Maranatha; 2012.

5. Putra YA. Pengaruh pemberian Phyllanthus Niruri terhadap perlemakan hati pada Rattus Norvegicus dengan dislipidemia [Tesis]. Yogyakarta: 
Universitas Gadjah Mada; 2015.

6. Dontas IA, Marinou KA, Illiopoulos D, Tsantila N, Agrogiannis G, Papalois A, et al. Changes of blood biochemistry in the rabbit animal model in artherosclerosis research; a time- or stress-efect. Lipids in Health and Disease. 2011;10:139.

7. Danciu M, Mihailovici MS, Dima A, Cucu C. Atlas of Pathology (3th ed). Iasi: Gr T Popa, 2009.

8. Kumar V, Cotran RS, Robbins SL. Robbins and Cotran Pathology Basis of Disease (6th ed). Philadelphia: Elsevier Saunders, 2005; p. 39-40.

9. Mandal A. Fatty liver pathology. [Internet] 2013. [Dikutip 5 Feb 2016].

Available from: URL:

http://www.news-medical.net/health/

Fatty-Liver-Pathology.aspx
10. Chan WHA, Quaglia A, Haugk B, Burt A. Atlas Liver of Pathology (1st ed). New York: Springer-Verlag; 2014; p. 77-80.

11. Hermanto S, Muawanah A. Profil dan karakeristik lemak hewani (ayam, sapi dan babi) Hasil Analisa FTIR dan GCMS. Jurnal Valensi. 2008;1(3):102-08.

12. Sartika RAD. Pengaruh asam lemak jenuh, tidak jenuh dan asam lemak trans terhadap kesehatan. Jurnal Kesehatan Masyarakat Nasional. 2008;2(4):15557.

13. Tanto C, Liwang F, Hanifari S, Pradipta EA. Kapita Selekta Kedokteran (4th ed). Jakarta: Media Aesculapius, 2014; p. 676. 